\title{
Utilization of [6]-gingerol as an origin discriminant marker influencing melanin inhibitory activity relative to its content in Pinellia ternata
}

\author{
Ju Hyeon An ${ }^{1}$ (D) $\cdot$ Hyo Jun Won ${ }^{1}$ (D) $\cdot$ Soo-Kyung Seo ${ }^{2}$ (D) Doo-Young Kim ${ }^{1}$ (D) \\ Chang-Sub Ku${ }^{2}$ (D) Sei-Ryang $\mathrm{Oh}^{1}$ (D) Hyung Won Ryu ${ }^{1}$
}

\section{반하(Pinellia ternata)에서의 [6]-gingerol 함량과 멜라닌 저해 활성에 영향을 미치는 원산지 판별 마커로의 활용}

안주현 $^{1}$ - 원효준 ${ }^{1}$ - 서수경 ${ }^{2}$ - 김두영1 - 구창섭 ${ }^{2}$ - 오세 량1 · 류형 원 ${ }^{1}$

Received: 19 July 2016 / Accepted: 1 September 2016 / Published Online: 31 December 2016

(C) The Korean Society for Applied Biological Chemistry 2016

\begin{abstract}
Pinellia ternata Breitenbach, the natural medicinal plant of the Araceae family, is a perennial plant originated from the East Asia, but also widely distributed in Europe and North America. Its tuber is used as traditional medicine for treatment of various diseases such as vomiting, inflammation, and traumatic injury. Pharmacological studies revealed that $P$. ternata possesses anticonvulsant, anti-tumor, insecticidal, and cytotoxic activities. Despite being well-known as the useful medicinal plant, there is no reliable, standardized method for origin discrimination. Ultra performance liquid chromatography-photodiode array detector and quadrupole time of flight-mass spectrometry based metaboliteprofiling was applied to explore significant metabolite for origin discrimination between Korean and Chinese P. ternata. One compound was isolated from Korean $P$. ternata using repeated ODS column chromatography by bioactivity guided fractionation, and determined as [6]-gingerol according to the results of
\end{abstract}

Hyung Won Ryu $(\triangle)$

E-mail: ryuhw@kribb.re.kr

${ }^{1}$ Natural Medicine Research Center, Korea Research Institute of Bioscience and Biotechnology, 30, Yeongudanji-ro, Ochang-eup, Cheongwon-gu, Cheongju-si, Chungbuk 28116, Republic of Korea

${ }^{2}$ Cotde Inc. 2708-28, Iljudong-ro, Gujwa-eup, Jeju-si, Jeju 63359, Republic of Korea

This is an Open Access article distributed under the terms of the Creative Commons Attribution Non-Commercial License (http://creativecommons. org/licenses/by-nc/3.0/) which permits unrestricted non-commercial use, distribution, and reproduction in any medium, provided the original work is properly cited. spectroscopic data including nuclear magnetic resonance and MS. This compound was selected as cosmeceutical biomarker by fingerprints, and it was associated to melanin inhibitory effect determining its origin authenticity. Furthermore, the calibration curve of biomarker was prepared using validated method for the comparison of content between Korean and Chinese P. ternata. This is the report to address the selection and successful validation of the discriminant metabolite for confirmation of Korean $P$. ternata.

Keywords [6]-gingerol $\cdot$ Korean marker $\cdot$ Melanin $\cdot$ Pinellia ternata

\section{서 론}

반하(Pinellia ternata)는 천남성과(Araceae)의 다년생 식물로써 주로 동아시아 일대(중국, 일본, 한국)에 서식하는 식물이다(Peng 등, 2007). 한방에서는 괴경(tuber)을 약재로 사용하여 거담, 구 토, 경련, 기침 등을 해소하는 목적으로 사용되고 있다 $(\mathrm{Ji}$ 등, 2014). 보고된 약리학적 작용으로는 진해, 진토, 항균, 정균, 항 염, 항산화, 진정, 면역, 항비만, 항암 등이 있는 것으로 알려져 있다(Gonda 등, 1994; Kim 등, 2001; Chen 등, 2003; Kim 등, 2006; Nagai 등, 2010; Zuo 등, 2012; Ahmed 등, 2013; Zhang 등, 2013; Iwasa 등, 2014; Kim 2015).

최근 약용작물 시장의 규모가 확대되면서, 전 세계적으로 약 재들의 무역이 증가하는 추세이다. 한국의 2014년 약재 수입량 
은 1억 228만 달러에 이르며, 2013년 약재 수입량인 1억 122만 달러 대비 $109.25 \%$ 의 증가세를 보이고 있다. 특히, 주요 무역 국인 중국으로부터 많은 약재들이 한국으로 대량 수입되고, 반 하 또한 최근 중국과의 무역을 통해 2014년 282.9톤으로 약재 수입량 상위 10 개 품목 중 8 번째로 많이 수입되어 국내에서 시 판되는 약재이다(Kim 2015). 시중에 판매되고 있는 반하는 주 로 한국산 반하와 중국산 반하이다. 한국산 반하는 중국산 반하 에 비해 높은 가격에 거래되고 있는데, 이는 중국산 반하가 중 금속이나 화학물질에 오염되었을 가능성과 한국산 반하가 중국 산 반하에 비해 더욱 뛰어난 효능을 지닐 것이라는 국내 소비 자들의 믿음에서 비롯된 것이다. 하지만, 최근 이러한 소비자 심 리를 이용하여 부당 이익을 취할 목적으로 중국산 반하를 한국 산 반하로 둔갑하여 불법적으로 판매하는 현상이 증가하였고, 이를 해결하기 위해 한국산 반하와 중국산 반하를 구별하기 위 한 연구가 증가하고 있다. 전통적으로, 한국에서는 약재들을 형 태학적, 조직학적으로 판별하는데, 한국산 반하와 중국산 반하는 형태가 매우 유사하여 이를 판별하기 어려운 실정이다. 이를 해 결하고자 반하에 대한 분자생물학적 판별법이 연구되었고, randomly amplified polymorphic DNA 분석과 PCR-restriction fragment length polymorphism 분석을 통해 한국산 반하와 중국 산 반하를 분자생물학적으로 판별할 수 있게 되었다(Chung 등, 2002). 하지만, 분자생물학적 판별법보다 간단히 수행할 수 있는 활성과 연관된 화학적인 접근을 통한 한국산과 중국산 반하의 원산지 판별 화합물 발굴에 대한 연구는 미비한 실정이다.

최근 천연물 소재의 품질 관리와 표준화의 중요성이 대두되 면서, MS기반 대사체 분석을 통한 마커 탐색에 대한 연구가 활 발히 진행되고 있다. 특히, 우리나라 특산품인 인삼에 대한 지 역별 혹은 국가별 판별 마커 연구가 보고되어 있으며, 한국산 백삼의 경우 notoginsenoisde R2와 ginsenoside Ro가 판별 화 합물로 보고되어 원산지를 판별하는 데 중요한 마커로 활용되 고 있다(Song 등, 2014). 또한, 대사체의 다변량 분석을 통해 겨우살이에서 동일한 속의 종을 판별할 수 있는 활성 타겟 마 커를 도출하여 화학적 분류(chemotaxonomy)에 활용되는 접근 방법이 보고되어 있다(Song 등, 2016).

본 연구에서는 한국산과 중국산 반하를 판별할 수 있는 화합 물을 ultra performance liquid chromatography-photodiode array detector (UPLC-PDA)와 quadrupole time of flight-mass spectrometry (QTof-MS)를 이용한 fingerprint 기법을 통해 확인하였고, 한국산 반하로부터 medium pressure liquid chromatography (MPLC) 기반 활성유도 분획법을 이용하여 타겟 화합물을 분리 및 구조 동정하여 멜라닌 저해 활성을 지닌 한국산 유효 및 원 산지 판별 마커로의 활용 가능성을 확인하였다. 또한, 판별 화 합물의 검량곡선을 작성하고, 검출한계와 정량한계를 산출하여 분석법에 대한 유효성을 검증하였다. 한국산과 중국산 반하의 판별 화합물에 대한 정량 및 크로마토그램을 비교 분석한 결과, 한국산 반하의 약용화장품 원료로서의 우수성을 확인하였다.

\section{재료 및 방법}

\section{실험 재료}

본 실험에서 사용한 한국산 반하(5종)와 중국산 반하(8종)는 2015년 국내 유통 도매시장에서 구매하여 확보하였고, 한국생 명공학연구원 한국식물추출물은행에서 동정하고 보관하였다. 수 집된 반하에 대한 자세한 정보는 Table 1에 나타내었다.

\section{시약 및 기기}

실험에 사용한 세포주인 $\mathrm{B} 16 \mathrm{~F} 10$ cell은 한국 세포주 은행 (Korean Cell Line Bank)으로부터 구입하였으며 세포배양을 위 해 $1 \%$ antibiotic과 $10 \%$ fetal bovine serum (FBS), phosphate buffered saline, Dulbeccos's Modified Eagle's Medium (DMEM) 은 Gibco (Rockville, MD, USA)에서 구입하였다. 세포 독성과 melanin 생합성 저해 활성 평가를 위해 non-radioactive cytotoxicity assay kit (Promega, Madison, WI, USA)를 사용하였고, 3(4,5-dimethylthiaxo-2-yl)-2,5-diphenyl tetrazolium bromide (MTT), $\alpha$-melanocyte stimulating hormone ( $\alpha$-MSH), dimethyl sulfoxide (DMSO)는 Sigma-Aldrich (St. Louis, MO, USA)에서 구입하 여 사용하였다. Melanin 생합성 저해 활성은 SpectraMax M5 (Molecular Devices, Sunnyvale, CA, USA)로 측정하였다. Ethanol $(\mathrm{EtOH})$ 용매 $(\mathrm{SK}$ chemical, KR)는 추출물 제조를 위해 사용하였으며, 타겟 화합물 분석과 분리를 위해 high performance liquid chromatography (HPLC)용 methanol (MeOH,

Table 1 The list of five Korean P. ternata and eight Chinese P. ternata

\begin{tabular}{ccc}
\hline Sample name & Origin & Supplier \\
\hline KPT-1 & Korea (Jeju) & Cotde Inc. (contract farming) \\
KPT-2 & Korea (Jeju) & Cotde Inc. (contract farming) \\
KPT-3 & Korea (Sancheong) & GyeongNam Oriental Medicinal Herb Institute \\
KPT-4 & Korea (Seosan) & Korea Herb Medicine Distribution Association \\
KPT-5 & Korea (Jecheon) & Jecheon Herb Co. \\
CPT-1 & China & Unkok Herb Co. \\
CPT-2 & China & Miryung Co. \\
CPT-3 & China & Hyunjin Co. \\
CPT-4 & China & Johwa Co. \\
CPT-5 & China & PBC470 \\
CPT-6 & China & PBC471 \\
CPT-7 & China & PBC472 \\
CPT-8 & China & PBC473 \\
PBC474 & PByoung Coung Co. \\
\hline
\end{tabular}


Honeywell, Moris Plains, NJ, USA)과 acetonitrile (ACN, Honeywell, Moris Plains, NJ, USA), formic acid (SigmaAldrich, St. Louis, MO, USA), leucine enkephalin (SigmaAldrich, USA)를 사용하여 UPLC-QTof-MS (Waters, Milford, MA, USA), PDA (Waters, Milford, MA, USA), MPLC (Gilson, Middleton, WI, USA), preparative-HPLC (PLC, Gilson, Middleton, WI, USA) 기기를 이용하여 진행하였다. 구조분석을 위해 Bruker AM400 ('H nuclear magnetic resonance (NMR) at $400 \mathrm{MHz},{ }^{13} \mathrm{C} \mathrm{NMR}$ at $100 \mathrm{MHz}$, Billerica, MA, USA)에 chloroform-d (Cambridge Isotope Laboratories, Andover, MA, $\mathrm{USA}$ )를 사용하여 분석하였다.

\section{한국산 반하를 이용한 칼럼분획물 제조}

음건한 한국산 반하 $6 \mathrm{~kg}$ 을 tube mill (IKA, Staufen, Germany) 을 이용하여 잘게 분쇄하고 $94 \%$ ethanol $(94 \% \mathrm{EtOH}, 10$ $\mathrm{L} \times 3)$ 을 가하여 실온에서 24 시간 3 회 반복 추출한 후 여과하였 다. 얻어진 여액을 감압 농축하여 $94 \% \mathrm{EtOH}$ 추출물 $(24.2 \mathrm{~g}$, 수율 $0.40 \%$ )을 얻었다. MPLC 기기에 $250 \times 20 \mathrm{~mm}$ 의 YMCPack ODS-AQ-HG (10 mm, YMC, Kyoto, Japan) 칼럼관과 ultraviolet (UV) 검출기 $(230,280 \mathrm{~nm})$ 장착한 후, 추출물 $4.0 \mathrm{~g}$ 을 로딩하였고, 증류수와 $\mathrm{MeOH}$ 의 혼합 용매를 이동상으로 하 여 $\mathrm{MeOH}$ 농도를 점차적으로 증가시키면서 $(50 \rightarrow 100 \%, 120$ $\min$ ) 칼럼분획물을 제조하였다. 칼럼분획물을 제조한 후, 각 분 획물에 대하여 UPLC-PDA와 연계하여 활성유도 분획법을 통 하여 유효성분을 분리하고자 하였다.

\section{UPLC-PDA를 이용한 한국산 반하 칼럼분흭물 분석}

유효성분 화합물의 위치를 확인하기 위해, UPLC에 $\mathrm{BEH} \mathrm{C}_{18}$ $(2.1 \times 100 \mathrm{~mm}, 1.7 \mathrm{~mm})$ 칼럼관과 photodiode array (PDA) 검출 기를 장착하고 칼럼오븐의 온도를 $35^{\circ} \mathrm{C}$ 로 유지하여 각 분획물 에 대한 분석을 진행하였다. $\mathrm{A}$ 용매는 $0.1 \%$ formic acid가 포 함된 증류수로, $\mathrm{B}$ 용매는 $0.1 \%$ formic acid가 포함된 $\mathrm{ACN}$ 으로 준비하였다. UPLC 이동상 조건은 $0-1 \mathrm{~min} 10 \% \mathrm{~B}, 1-2 \mathrm{~min}$ $50 \% \mathrm{~B}, 2-8 \min 100 \% \mathrm{~B}, 8-10 \min 100 \% \mathrm{~B}, 10-10.5 \mathrm{~min}$ $10 \% \mathrm{~B}, 10.5-13.0 \mathrm{~min} 10 \% \mathrm{~B}$ 를 유속 $0.4 \mathrm{~mL} / \mathrm{min}$ 로 흘렸으 며, 시료는 $5 \mathrm{~mL}(2 \mathrm{mg} / \mathrm{mL})$ 주입하여 분석을 실시하였다.

\section{한국산 반하 칼럼분획물의 세포 독성 및 활성측정을 위한 세포 배양}

마우스 멜라노마 세포인 $\mathrm{B} 16 \mathrm{~F} 10$ cell을 각각 $1 \%$ antibiotic과 $10 \% \mathrm{FBS}$ 가 함유된 $\mathrm{DMEM}$ 배지를 사용하여 $37^{\circ} \mathrm{C}, 5 \% \mathrm{CO}_{2}$ incubator에서 배양하였다.

\section{한국산 반하 칼럼분획물의 세포 독성 측정}

$\mathrm{B} 16 \mathrm{~F} 10$ cell을 $2.0 \times 10^{4}$ cells $/ \mathrm{mL}$ 로 96 well plate에 분주하고 18 시간 배양 후 샘플을 $50 \mathrm{mg} / \mathrm{mL}$ 농도로 조제하여 첨가하고 24시간 배양하였다. 이후 MTT 용액 $100 \mathrm{~mL}$ 를 첨가하여 4시간 동안 반응 시켰다. 배양배지를 완전히 제거하고 DMSO 200 $\mathrm{mL}$ 를 가하여 침전물을 완전히 용해시킨 후, microplate reader 를 사용하여 $540 \mathrm{~nm}$ 흡광도를 측정하였다. 각 샘플 군에 대한 평균 흡광도 값을 구하였으며, 대조군의 흡광도 값과 비교하여 세포생장률을 측정하였다.

\section{한국산 반하 칼럼분흭물의 melanin 생합성 저해 활성 측정}

$\mathrm{B} 16 \mathrm{~F} 10$ cell을 $\mathrm{DMEM}$ 배지를 이용하여 $2.0 \times 10^{4}$ cells $/ \mathrm{mL}$ 로 24 well plate에 분주하고 $\alpha-\mathrm{MSH}(200 \mathrm{nM})$ 로 활성화 시킨 후 24 시간 배양 후 샘플을 $50 \mathrm{mg} / \mathrm{mL}$ 농도로 조제하여 첨가한 후 48시간 후에 $0.1 \mathrm{M}$ potassium phosphate buffer ( $\mathrm{pH}$ 7.4)으로 세척하였다. 그 다음 melanin에 $1 \mathrm{~N} \mathrm{NaOH}$ 를 가하여 $80^{\circ} \mathrm{C}$ 에 서 1시간 반응시킨 후 분광광도계 $405 \mathrm{~nm}$ 에서 흡광도를 측정 하였다(Jeon 등, 2012). Melanin 생합성 저해는 샘플 용액의 첨 가군과 무첨가군의 흡광도 감소율로 나타내었다.

\section{타겟 판별 화합물 분리 및 구조분석}

타겟 판별 화합물이 풍부한 칼럼분획물(KPT Fr. 9)을 농축하여 prep-HPLC 칼럼(YMC-Pack ODS-AQ, $250 \times 20 \mathrm{~mm}, 5 \mathrm{~mm}$, $\mathrm{YMC}$ )를 사용하여 유속은 $14 \mathrm{~mL} / \mathrm{min}$ 로 $\mathrm{A}$ 용매는 증류수, $\mathrm{B}$ 용 매는 $\mathrm{ACN}$ 을 혼합용매로 사용하여 $0-5 \mathrm{~min} 60 \% \mathrm{~B}, 5-35 \mathrm{~min}$ $100 \% \mathrm{~B}, 35-40 \mathrm{~min} 100 \% \mathrm{~B}$ 조건으로 $\mathrm{ACN}$ 을 순차적으로 증가시켜 타겟 판별 화합물 1종을 분리하였다. 그 후, UPLCQTof-MS에 $\mathrm{BEH} \mathrm{C}_{18}(2.1 \times 100 \mathrm{~mm}, 1.7 \mathrm{~mm})$ 칼럼관과 PDA 검출기를 장착하고 칼럼오븐의 온도를 $35{ }^{\circ} \mathrm{C}$ 로 유지하여 분석 을 진행하였다. A용매는 $0.1 \%$ formic acid가 포함된 증류수로, $\mathrm{B}$ 용매는 $0.1 \%$ formic acid가 포함된 $\mathrm{ACN}$ 으로 준비하였다. $\mathrm{UPLC}$ 이동상 조건은 $0-1 \min 10 \% \mathrm{~B}, 1-2 \min 50 \% \mathrm{~B}, 2-8$ $\min 100 \% \mathrm{~B}, 8-10 \min 100 \% \mathrm{~B}, 10-10.5 \min 10 \% \mathrm{~B}, 10.5-$ $13.0 \mathrm{~min} 10 \% \mathrm{~B}$ 를 유속 $0.4 \mathrm{~mL} / \mathrm{min}$ 로 흘렸으며, 시료는 2 $\mathrm{mL}(50 \mathrm{mg} / \mathrm{mL})$ 주입하였다. $\mathrm{MS}$ 분석에서 이온화 방법을 electron spray ionization으로 채택하였고, positive로 capillary voltage $2300 \mathrm{~V}$, ion source temperature $110{ }^{\circ} \mathrm{C}$, desolvation gas $\left(\mathrm{N}_{2}\right)$ 유속 $800 \mathrm{~L} / \mathrm{h}$, mass scan 범위 $m / z$ 100-1500, lockspray reference로 luecine enkephalin을 사용하였다. 정확한 구조 분석 을 위해, 분리된 타겟 화합물에 대한 NMR 분석을 실시하였고, $\mathrm{MS}$ 를 이용하여 얻은 분광학적 정보와 $\mathrm{NMR}$ 분석 데이터를 종 합하여 구조를 동정하였으며, 이전의 참고문헌과 비교하여 최종 확인하였다(Jiang 등, 2005; Kim 등, 2008).

\section{화합물 1 ([6]-gingerol)}

연황색 오일, $[\beta]_{20}^{\mathrm{D}}=+27.8^{\circ}\left(c=1.0, \mathrm{CHCl}_{3}\right)$, HRESIMS $\mathrm{m} / \mathrm{z}$ $=277.1813\left[\mathrm{M}-\mathrm{H}_{2} \mathrm{O}+\mathrm{H}\right]^{+}$(calcd for $\mathrm{C}_{17} \mathrm{H}_{24} \mathrm{O}_{3}, 277.1804$ ), $\lambda_{\max }$ $(\mathrm{MeOH}) 223,280 \mathrm{~nm} .{ }^{1} \mathrm{H}-\mathrm{NMR}\left(400 \mathrm{MHz}, \mathrm{CDCl}_{3}\right) d_{\mathrm{H}} 6.69$ (1H. d, $J=2.0 \mathrm{~Hz}, \mathrm{H}-2), 6.60(1 \mathrm{H}, \mathrm{d}, J=8.4 \mathrm{~Hz}, \mathrm{H}-5), 6.53$ (1H, dd, J=8.4, $2.0 \mathrm{~Hz}, \mathrm{H}-6), 3.86$ (1H, m, H-5'), 3.74 $\left(3 \mathrm{H}, \mathrm{s}, \mathrm{OCH}_{3}\right), 2.69\left(4 \mathrm{H}, \mathrm{s}, \mathrm{H}-1^{\prime}, \mathrm{H}-2^{\prime}\right), 2.44(2 \mathrm{H}, \mathrm{dd}$, $\left.J=8.4,2.0 \mathrm{~Hz}, \mathrm{H}-4^{\prime}\right), \quad 1.21-1.32 \quad\left(8 \mathrm{H}, \mathrm{m}-\left(\mathrm{CH}_{2}\right)_{2}, \mathrm{H}-6^{\prime}-\mathrm{H}_{-} 9^{\prime}\right)$ $0.83\left(3 \mathrm{H}, \mathrm{t}, \mathrm{H}-10^{\prime}\right) ;{ }^{13} \mathrm{C}-\mathrm{NMR}(100 \mathrm{MHz}, \mathrm{CDCl} 3) d_{\mathrm{C}} 14.7$ (C-10'), 24.0 (C-9'), 26.6 (C-8'), 30.6 (C-1'), 33.2 (C-7'), 38.7 (C-6'), 46.7 (C-2'), $51.6\left(\mathrm{C}-4^{\prime}\right), 56.6\left(\mathrm{OCH}_{3}\right), 69.2$ (C5'), 113.3 (C-2), 116.3 (C-5), 121.9 (C-6), 134.2 (C-1), 145.9 (C-4), 149.0 (C-3), 212.1 (C-3').

\section{분석법 유효성 검중}

타겟 판별 화합물을 $\mathrm{MeOH}$ 에 녹여 stock solution을 만든 후, $0-100 \mathrm{mg} / \mathrm{mL}$ 범위 내에서 8개 농도로 희석하여 표준용액을 제 조하였다. 실험적 오차를 줄이고, 반복성(repeatability)과 재현성 
(reproducibility), 정밀성(precision)을 확보하기 위해 제조한 표 준용액을 UPLC-PDA를 이용하여 UV $230 \mathrm{~nm}$ 에서 각각 3 반복 분석을 실시하였고, 농도에 따른 피크의 면적을 단순 선형회귀 곡선의 형태로 구하여 검량곡선을 작성하였다. 작성된 검량곡선 의 직선성(linearity)은 결정계수(coefficient of determination, $\mathrm{R}^{2}$ )를 통하여 판단하였으며, 검출한계(limit of detection, $\mathrm{LOD}$ ) 와 정량한계(limit of quantification, $\mathrm{LOQ}$ )는 검량곡선의 평균 기울기와 검량식 절편의 표준편차에 근거하여 산출하였다.

\section{한국산과 중국산 반하 추출물 샘플 제조}

국내 유통시장에서 확보한 한국산 반하(5종)과 중국산 반하(8종) 을 음건하여 각각 Tube mill (IKA, Staufen, DE)을 이용하여 $10 \mathrm{~g}$ 씩 잘게 분쇄하였다. 그리고, $94 \%$ ethanol $(94 \% \mathrm{EtOH}$, $100 \mathrm{~mL} \times 3$ )을 가한 후, 초음파 추출법(ultrasonication extraction) 을 이용하여 3 회 반복 추출, 여과하였다. 얻어진 여액을 감압 농축하여 각각의 추출물을 얻은 후, $94 \% \mathrm{EtOH}$ 에 녹여 50 $\mathrm{mg} / \mathrm{mL}$ 의 균일한 농도로 샘플을 제조하였다.

\section{한국산과 중국산 반하 추출물의 UPLC-PDA 분석}

한국산과 중국산 반하의 $94 \%$ 에탄올 추출물로부터 타겟 판별 화합물을 확인하기 위해 $\mathrm{UPLC}$ 에 $\mathrm{BEH} \mathrm{C}_{18}(2.1 \times 100 \mathrm{~mm}, 1.7$ $\mathrm{mm}$ ) 칼럼관과 $\mathrm{PDA}$ 검출기를 장착하고 칼럼오븐의 온도를 35 ${ }^{\circ} \mathrm{C}$ 로 유지하여 분석을 진행하였다. $\mathrm{A}$ 용매는 $0.1 \%$ formic acid 가 포함된 증류수로, $\mathrm{B}$ 용매는 $0.1 \%$ formic acid가 포함된 $\mathrm{ACN}$ 으로 준비하였다. UPLC 이동상 조건은 $0-1 \min 10 \% \mathrm{~B}$, $1-2 \min 50 \% \mathrm{~B}, 2-8 \min 100 \% \mathrm{~B}, 8-10 \min 100 \% \mathrm{~B}, 10-$ $10.5 \mathrm{~min} 10 \% \mathrm{~B}, 10.5-13.0 \mathrm{~min} 10 \% \mathrm{~B}$ 를 유속 $0.4 \mathrm{~mL} / \mathrm{min}$ 로 흘렸으며, 시료는 $5 \mathrm{~mL}(50 \mathrm{mg} / \mathrm{mL})$ 주입하여 무작위 3 반복 분석을 실시하였다.

\section{타겟 판별 화합물 정량 및 크로마토그램 비교분석}

한국산 반하(5종)과 중국산 반하(8종)의 타겟 판별 화합물을 정 량하고 그 함량을 서로 비교하기 위해, UPLC-PDA 크로마토그 램(UV $230 \mathrm{~nm}$ )에서 타겟 판별 화합물에 해당하는 피크 면적을 적분을 통해 구하였다. 피크 면적값을 검량식에 대입하여 각각

(A)

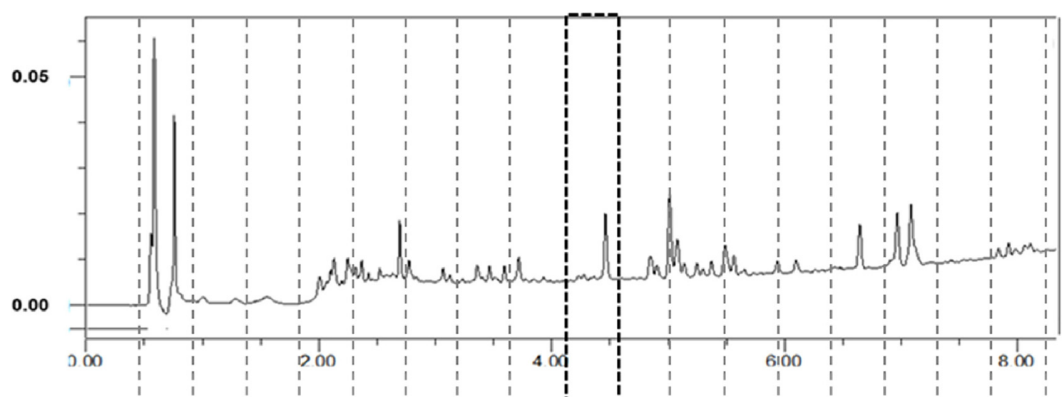

(B)

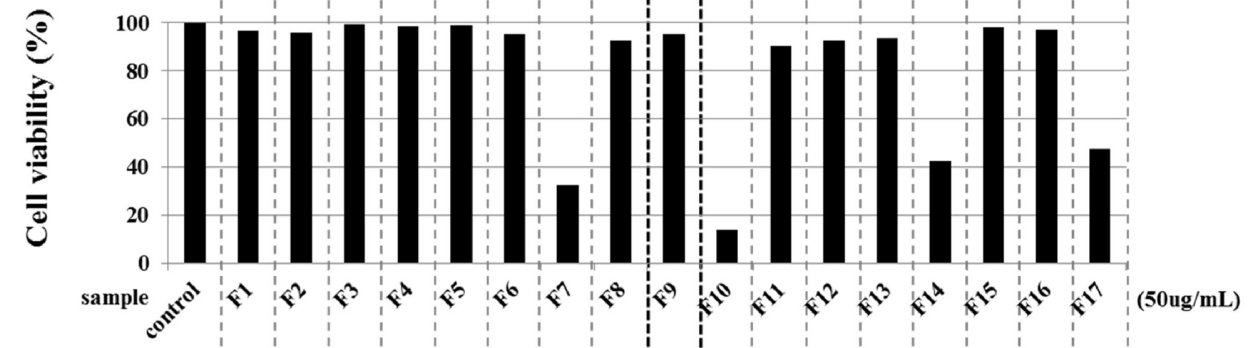

(C)

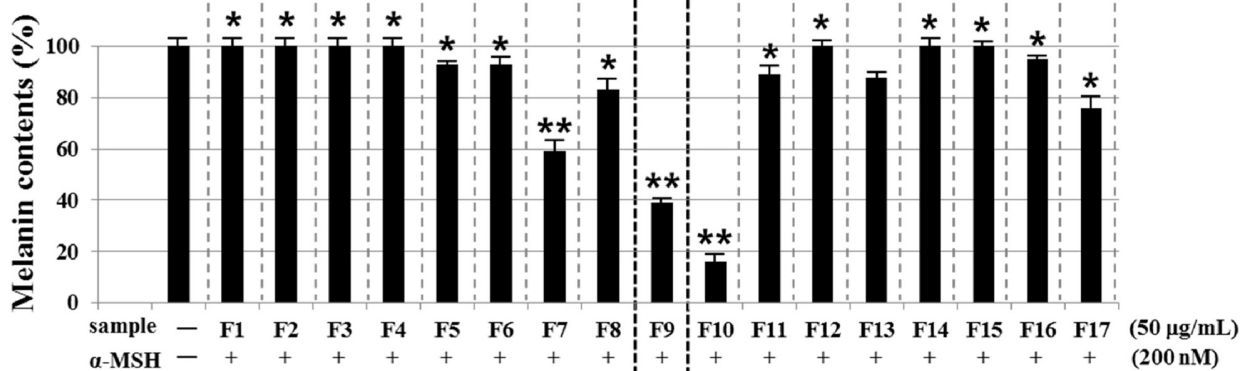

Fig. 1. (A) UPLC-PDA chromatogram of $94 \%$ ethanol extracts of Pinellia ternata for bioactivity-guided fractionation. (B) Effect of KPT Fr.1-17 fractions on the growth of B16F10 melanoma cells. Cytotoxicity was measured by MTT assay of fractions and control (DMSO) treated B16F10 melanoma cells after $24 \mathrm{~h}$ at $50 \mathrm{mg} / \mathrm{mL}$ concentration. (C) Effect of 1-17 fractions on melanogenesis in B16F10 cells cultured with $50 \mathrm{mg} / \mathrm{mL}$ for 2 days. Changes of melanin contents that were pretreated with $\alpha$-melanocyte-stimulating hormone ( $\alpha$-MSH) and then cultured with fractions for 48 h. Results were expressed as the mean $\pm \mathrm{SD}$ of three independent experiments. ${ }^{*} p<0.01$ compared to the control (no treatment) and $* * p<0.005$ compared to the control 
의 시료에 대한 타겟 판별 화합물의 함량을 산출하여 서로 비 교하였고, 한국산과 중국산 반하의 크로마토그램을 overlay하여 비교 분석하였다.

\section{결과 및 고찰}

\section{한국산 반하 칼럼분획물 제조}

국내산 반하의 타겟 유효성분 화합물을 분리하고 구조동정하기 위해 MPLC 기기에 YMC-Pack ODS-AQ-HG (10 mm, YMC) 칼럼관과 $\mathrm{UV}$ 검출기 $(230,280 \mathrm{~nm})$ 장착한 후, 추출물 $4.0 \mathrm{~g}$ 을 로딩하여 증류수와 $\mathrm{MeOH}$ 의 혼합 용매를 이동상으로 하여 $\mathrm{MeOH}$ 농도를 점차적으로 증가시키면서 $(50 \rightarrow 100 \%, 120 \mathrm{~min})$ UPLC-PDA와 연계한 활성유도 분획법(bioactivity-guided fractionation)을 병행하며 역상 칼럼 크로마토그래피를 실시하였 다. 그 결과, 총 17 개의 분획물(KPT Fr.1-Fr.17)을 얻었다(Fig. 1A).

한국산 반하 칼럼분흭물의 세포독성 및 melanin 저해활성 측정 한국산 반하에서 분리된 칼럼분획물과 생리활성 사이의 유의적 인 활성관계를 추적하기 위해 17 개의 분획물들의 melanin 저해 효과를 확인하고자 하였다. 생리활성 평가에 앞서 활성과 세포 독성 사이의 상관관계를 MTT assay로 측정하였다. MTT assay 는 대사가 왕성한 살아있는 세포 내에 존재하는 mitochondria 의 탈 수소 효소작용에 의하여 수용성의 노란색인 MTT tetrazolium을 환원시켜 생성되는 자주색의 비수용성 formazan을 $\mathrm{UV}$ 로 측정하는 방법으로 수행하였다. 반하 칼럼분획물들의 세 포독성 결과, $\mathrm{KPT}$ Fr. 7, 10, 14,17 분획물들을 제외한 칼럼 분획물들이 $50.0 \mathrm{mg} / \mathrm{mL}$ 농도에서 세포 독성을 나타내지 않았 다(Fig. 1B). 세포독성이 없으며 melanin 저해활성이 뛰어난 한 국산 반하의 타겟 유효성분 화합물을 추적하기 위해 melanin 저해활성 역시 관찰하였다. $\mathrm{B} 16 \mathrm{~F} 10$ cell을 $\alpha-\mathrm{MSH}(200 \mathrm{nM})$ 로 활성화 시킨 후 칼럼분획물을 $50.0 \mathrm{mg} / \mathrm{mL}$ 농도로 처리하여 48 시간 후 생성되는 melanin의 함량을 측정하였다. 17개의 칼럼 분획물들 중 세포독성이 없으며 melanin 함량을 유의성 있게 저해하는 분획물은 retention time 4.45 분에 확인된 peak가 많이 함유된 KPT Fr. 9로 확인되었다(Fig. 1C).

\section{타겟 판별 화합물 분리 및 구조분석}

칼럼 유효분획물 중 타겟 유효성분 화합물의 양이 가장 많이 함유된 분획물 $\mathrm{KPT}$ Fr. 9를 농축하여 PLC로 $\mathrm{C}_{18}$ column (YMC-ODS-AQ)에 로딩 후, 증류수와 $\mathrm{ACN}$ 의 혼합 용매를 이 동상으로 하여 $\mathrm{ACN}$ 농도를 점차적으로 증가시키면서 $(60 \rightarrow 100$ $\%, 30 \mathrm{~min})$ 칼럼 크로마토그래피를 실시하였다. 1회 주입량을 $200 \mathrm{~mL}$ 로 하여 3 회 반복 실험을 통해 1 종의 활성 단일물질 $10.2 \mathrm{mg}$ 을 분리하였다. 분리된 타겟 판별 화합물을 $\mathrm{MS}$ 를 이용 하여 분석한 결과, retention time은 4.45 분으로 확인되었으며, 해당 피크는 $m / z=277.1813\left[\mathrm{M}-\mathrm{H}_{2} \mathrm{O}+\mathrm{H}\right]^{+}$(calcd for $\mathrm{C}_{17} \mathrm{H}_{25} \mathrm{O}_{3}$, $277.1804), \lambda_{\max }(\mathrm{MeOH}) 223,280 \mathrm{~nm}$ 를 가져 gingerol로 예상 되었고(Jiang 등, 2005), NMR을 이용하여 구조를 동정한 결과,

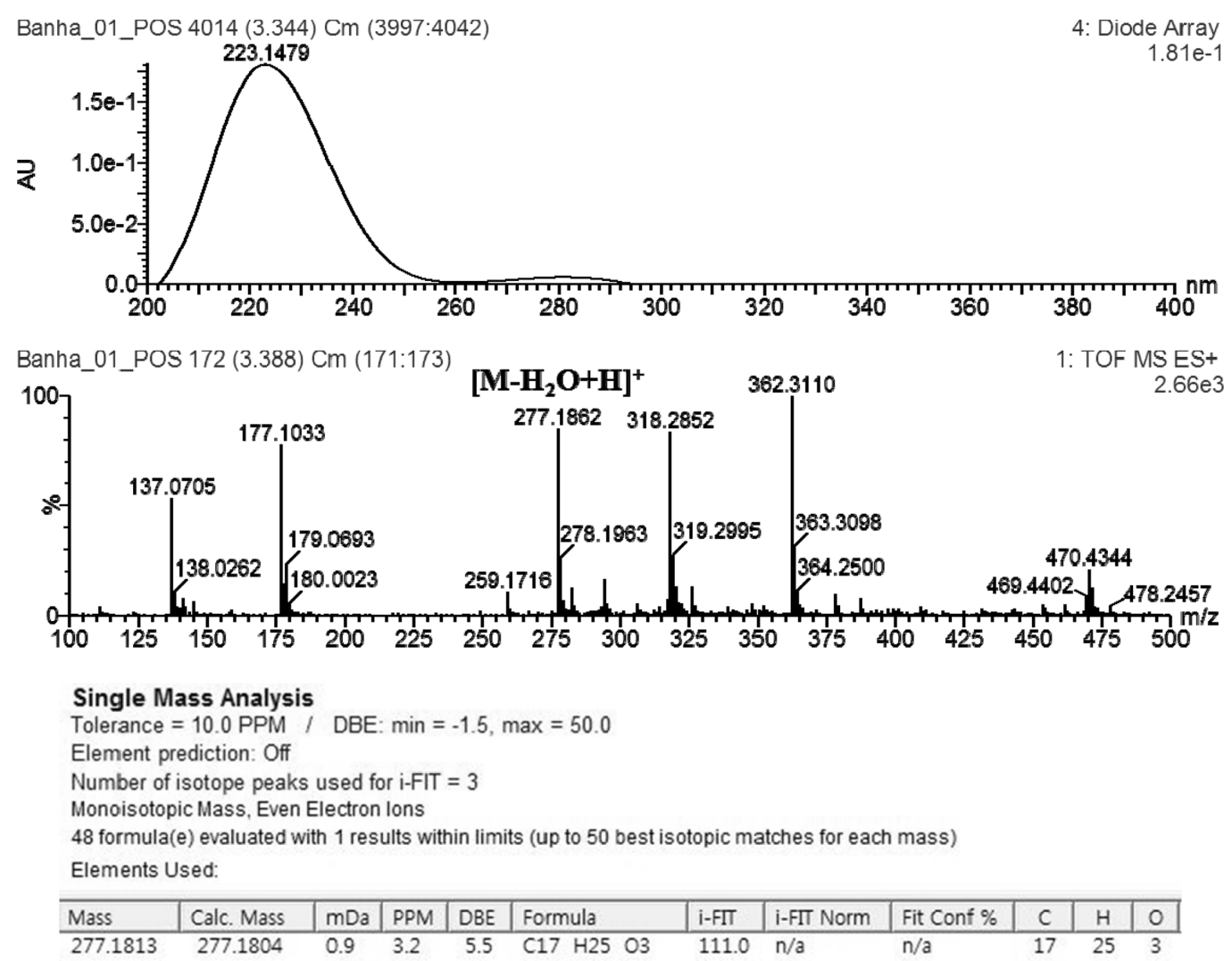

Fig. 2. UV spectrum, MS chromatogram and chemical structure, HRESIMS elemental composition of [6]-gingerol 


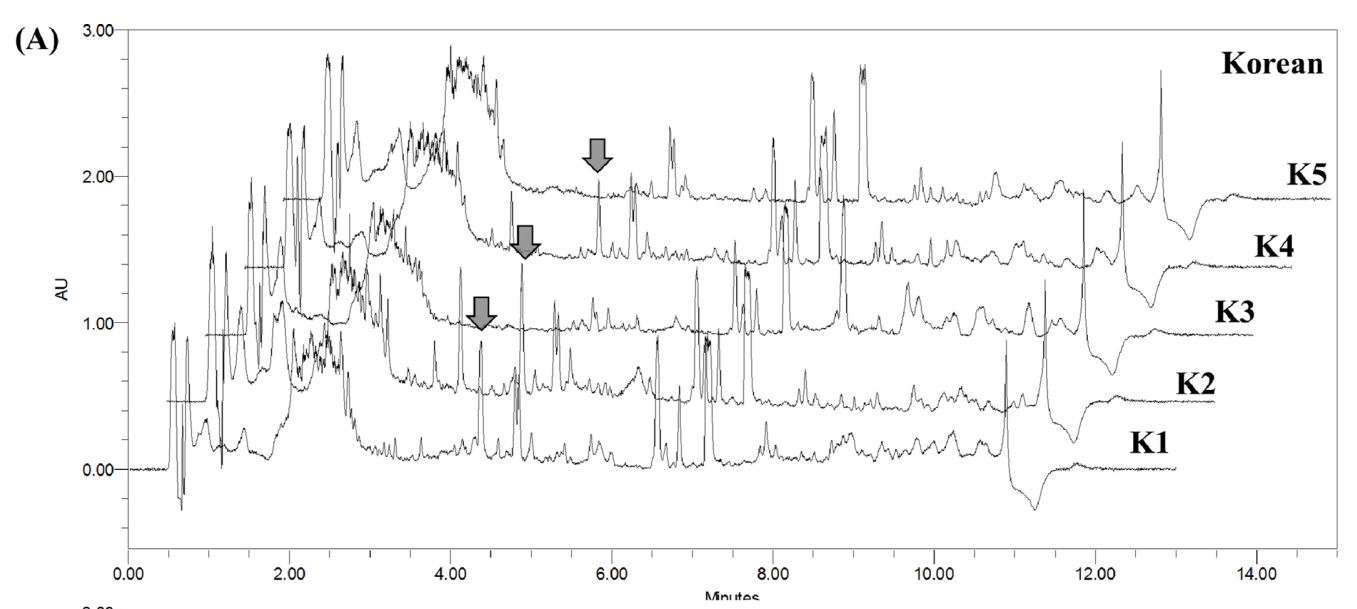

(B)

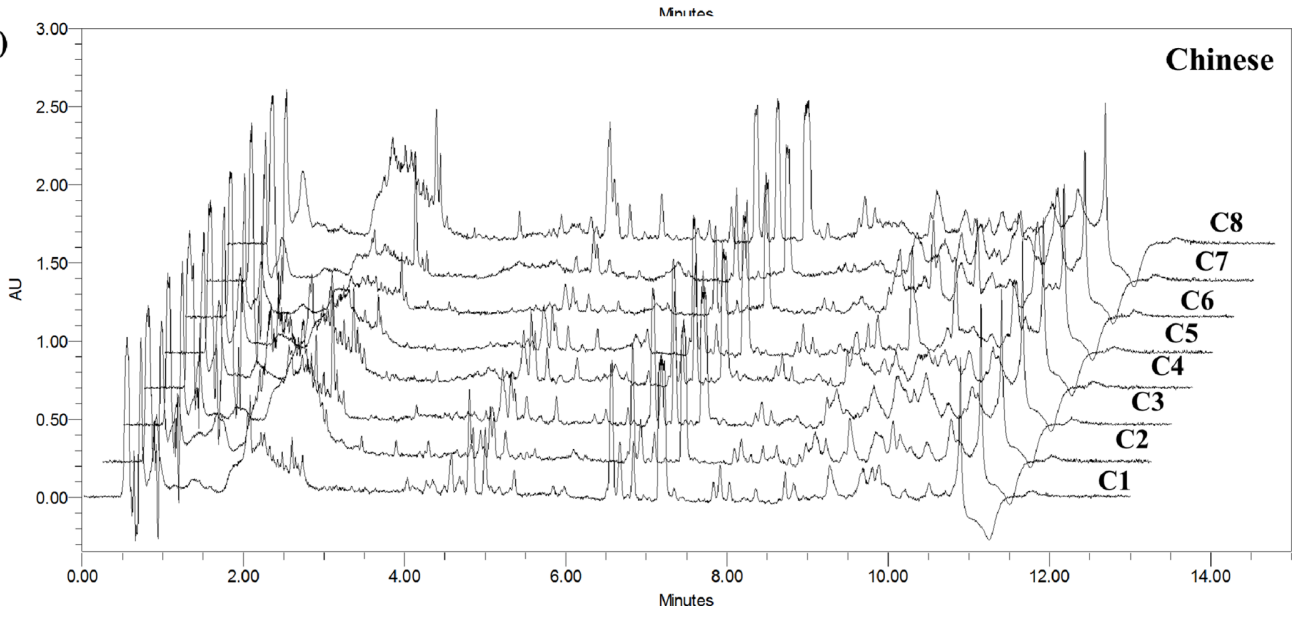

Fig. 3. Photodiode array (PDA) chromatograms (UV $230 \mathrm{~nm}$ ) of (A) five Korean P. ternata and (B) eight Chinese P. ternata. The peak at retention time 4.45 min was [6]-gingerol, and Korean $P$. ternata has large amounts of [6]-gingerol compared to Chinese $P$. ternata. The red arrows were indicated as the peak of [6]-gingerol

[6]-gingerol임을 확인하였고(Fig. 2), 선행문헌의 ${ }^{1} \mathrm{H},{ }^{13} \mathrm{C}-\mathrm{NMR}$ 데이터와 비교하여 [6]-gingerol임을 확인하였다(Kim 등, 2008). 본 연구는 처음으로 반하로부터 [6]-gingerol을 분리하여 구조 동정하고 보고하는 것이다. 이를 통해 표준화된 반하 소재를 이 용한 기능성 미백 소재로의 개발 가능성과 개발 제품의 유효성 분 QC (quality control) 화합물로 [6]-gingerol의 활용 가능성을 확인하였다. 이전에 gingerol에 대한 분석 연구는 생강에서 분 리된 [6]-gingerol의 GC-MS를 이용한 구조 분석과 멜라닌 저해 활성이었다(Ali 등, 2008; Huang 등, 2011).

\section{분석법 유효성 검중}

유효성분 화합물로 선정된 [6]-gingerol의 직선성 검증을 위한 표준시료 농도 범위는 $0-100 \mathrm{mg} / \mathrm{mL}$ 이었으며, 8 개 농도로 희석 하여 표준용액을 UPLC-PDA를 이용하여 [6]-gingerol 최대흡광 도 부근의 UV $230 \mathrm{~nm}$ 에서 3 반복 분석하였다. [6]-gingerol 검 량곡선의 직선성에 대한 회귀방정식은 $\mathrm{y}=12535 \mathrm{x}+6639.4$ 이었고 결정계수 $\left(\mathrm{R}^{2}\right)$ 는 0.9917 로 해당 분석조건 하에서 높은 직선성을 나타내었다. 직선성을 나타내는 범위 내에서 [6]-gingerol의 LOD 값과 $\mathrm{LOQ}$ 값은 각각 $0.90 \mathrm{mg} / \mathrm{mL}$ 과 $2.73 \mathrm{mg} / \mathrm{mL}$ 이었다(Table 2). 그리하여, 타겟 판별 화합물 [6]-gingerol 분석법은 유효성
검증을 통하여 직선성 및 정밀도, 반복성, 재현성을 지닌 것으 로 확인되었다.

\section{UPLC-PDA 분석을 통한 타겟 판별 화합물 정량 및 크로마토 그램 비교분석}

한국산 반하(5종)와 중국산 반하(8종)을 각각 $94 \%$ 에탄올로 추 출하였고, fingerprint 분석방법을 통해 한국산 판별 화합물을 확 인하기 위해 UPLC-PDA (UV $230 \mathrm{~nm}$ )에서 시료당 13분 동안 분석을 실시하였다. 한국산과 중국산 반하 추출물의 크로마토그 램을 overlay하여 비교한 결과, retention time 4.45분에 나타난 메인 화합물 [6]-gingerol의 피크가 한국산 반하에서 중국산 반 하에 비해 특이적으로 큰 피크 면적을 나타내었다(Fig. 3).

한국산과 중국산 반하의 타겟 판별 화합물 [6]-gingerol 함량 비교를 위해 검량곡선 회귀방정식을 이용하여 각 시료 별로 그 함량을 구하였다. UPLC-PDA 크로마토그램(UV $230 \mathrm{~nm})$ 에서 타겟 판별 화합물의 피크 적분값을 검량식에 대입하여 함량을 구하였고, 시료 별로 [6]-gingerol의 함량을 평균값과 표준편차 로 나타내었다(Table 3).

한국산과 중국산 반하의 [6]-gingerol의 함량을 분석한 결과, 한국산은 5종 중에서 제주도에서 재배된 반하 2종(KPT-1, KPT- 
Table 2 The measurement of linearity, LOD, and LOQ for [6]-gingerol

\begin{tabular}{|c|c|c|c|c|c|}
\hline Comp. & Range $(\mu \mathrm{g} / \mathrm{mL})$ & Linear model ${ }^{\mathrm{a}}$ & Coefficient of determination ${ }^{b}$ & $\operatorname{LOD}^{\mathrm{c}}(\mu \mathrm{g} / \mathrm{mL})$ & $\operatorname{LOQ}^{\mathrm{c}}(\mu \mathrm{g} / \mathrm{mL})$ \\
\hline [6]-gingerol & $0-100$ & $y=12535 x+6639.4$ & 0.9917 & 0.90 & 2.73 \\
\hline
\end{tabular}

${ }^{a} \mathrm{y}=$ peak area, $\mathrm{x}=$ concentration of standard $(\mathrm{ig} / \mathrm{mL})$

${ }^{\mathrm{b}}$ For eight points on the calibration curve, each concentration being injected three times

${ }^{\mathrm{c}} \mathrm{LOD}$ and LOQ are the limits of detection and quantitation, respectively

Table 3 The comparison to content of [6]-gingerol between Korean and Chinese P. ternata

\begin{tabular}{ccc}
\hline P. ternata & Sample name & Content $(\mathrm{g} / 100 \mathrm{~g})$ \\
\hline \multirow{5}{*}{ Korean } & KPT-1 & $0.58 \pm 0.05$ \\
& KPT-2 & $0.60 \pm 0.07$ \\
& KPT-3 & Trace \\
& KPT-4 & $0.31 \pm 0.03$ \\
KPT-5 & Trace \\
\hline \multirow{5}{*}{ Chinese } & CPT-1 & $0.03 \pm 0.01$ \\
& CPT-2 & $0.07 \pm 0.02$ \\
& CPT-3 & Trace \\
& CPT-4 & Trace \\
& CPT-5 & Trace \\
& CPT-6 & Trace \\
& CPT-7 & Trace \\
& CPT- 8 & $0.08 \pm 0.02$ \\
\hline
\end{tabular}

Each samples were injected in triplicate using UPLC-PDA at UV 230 $\mathrm{nm}$, and quantitative values were represented as average \pm standard deviation

2)과 서산에서 재배된 반하(KPT-4)에서 각각 $0.58 \pm 0.05,0.60 \pm 0.07$, $0.31 \pm 0.03 \mathrm{~g} / 100 \mathrm{~g}$ 의 함량을 나타내었다. 대부분의 중국산의 경 우, [6]-gingerol의 함량이 미비하지만 8종 중에 3종(CPT-1, CPT-2, CPT-8)에서 정량한계 범위 내에서 타겟 판별 화합물의 함량을 구할 수 있었으며, 이들은 각각 $0.03 \pm 0.01,0.07 \pm 0.02$, $0.08 \pm 0.02 \mathrm{~g} / 100 \mathrm{~g}$ 의 함량을 나타내었다. 한국산 중 제주도 및 서산 지역의 반하와 [6]-gingerol이 검출된 중국산 반하의 [6]gingerol 대사체의 함량을 비교한 결과, 한국의 제주도 및 서산 에서 재배된 반하가 [6]-gingerol이 확인된 중국산에 비해 함량 이 12 배 높은 것을 확인하였다. 그러므로 반하의 미백 바이오 마커인 [6]-gingerol은 함유량이 높게 나타난 한국 제주도 및 서 산 지역의 반하가 수입된 중국산 반하보다 미백 기능성화장품 소재로 적합성 나타내었다.

결론적으로 일부 한국산 반하에 대한 미백 바이오 판별 마커 로 선정된 [6]-gingerol은 추출물 및 칼럼분획물에서 가장 많은 양으로 함유된 단일성분으로 확인되었고, 유효성이 검증된 UPLC-PDA 크로마토그램을 통해 한국산과 중국산 반하를 비교 한 결과, retention time 4.45분에 나타난 메인 화합물 [6]gingerol의 피크 면적이 한국의 제주도 및 서산 지역의 반하에 서 대부분의 중국산 반하에 비해 특이적으로 큰 피크 면적을 나타냄을 확인하였다. 따라서, [6]-gingerol은 한국산 판별 마커 및 QC (quality control)를 위한 활용 가능성이 있음을 확인하 였고, fingerprint 분석방법을 이용한 유효성분 비교 결과에서도 melanin 저해활성과 판별 대사체 활용 가능성을 동시에 만족시
키는 중요한 미백 바이오 판별 마커로 확인되었다. 특히, 한국 의 제주도와 서산에서 재배된 반하의 경우, [6]-gingerol의 함량 이 일반적인 중국산에 비해 12 배 높은 함량을 나타냄을 최종 확인하였다. 그러므로 [6]-gingerol의 함량이 높은 한국산 지역 의 반하를 기능성 미백 화장품 소재 원료로 개발하는 것이 더 욱 합리적일 것으로 생각된다.

\section{초 록}

반하(Pinellia ternata Breitenbach)는 천남성과(Araceae)의 약용 식물로 동아시아 일대가 원산지이며, 유럽과 북아메리카 일부 지역에도 널리 분포하고 있는 식물이다. 반하의 괴경(tuber)은 약재로 사용되어 구토, 염증, 외상을 치료하는 목적으로 사용되 고 있다. 보고된 약리학적 작용으로는 항경련, 항종양, 살충, 세 포독성 등이 있는 것으로 알려져 있다. 반하는 약리학적으로 유 용한 약용식물로 잘 알려져 있음에도 불구하고, 원산지를 판별 할 수 있는 신뢰성이 있고 표준화된 방법이 없는 실정이다. 이 를 위한 한국산과 중국산 반하를 판별할 수 있는 유의적인 화 합물을 탐색하기 위해 UPLC-PDA와 QTof-MS에 기반을 둔 대 사체 표지법을 이용하였다. 한국산으로부터 원산지 판별 화합물 로 예상되는 화합물을 반복적인 역상 칼럼크로마토그래피에 기 반을 둔 활성유도 분획법을 통해 분리하였다. 그리고, NMR과 $\mathrm{MS}$ 를 포함한 물리화학적, 분광학적 정보의 결과를 토대로 [6]gingerol이라는 화합물의 구조를 동정하였다. [6]-gingerol은 원 산지를 판별할 수 있는 능력과 melanin 생합성 저해 활성을 지 닌 기능성 화장품 소재로서 가치가 있다고 판단되어짐에 따라 유효성분 원산지 판별 화합물로 Fingerprint법에 의해 선정되었 다. 더욱이, 한국산과 중국산 반하 유래 [6]-gingerol의 함량 비 교를 위해, 유효성이 검증된 분석법을 이용하여 이에 대한 검 량곡선을 작성하여 그 함량을 비교하였다. 이것은 한국산 반하 판별을 위한 화합물 선정과 성공적인 유효성 검증을 다룬 최초 의 보고이다.

Keywords 멜라닌 · 반하(Pinellia ternata) · 한국산 마커 · [6]-gingerol

\section{References}

Ahmed S, Hasan MM, Ahmed SW, Mahmood ZA, Azhar I, Habtemariam S (2013) Anti-emetic effects of bioactive natural products. Phytopharmacology 4:390-433

Ali BH, Blunden G, Tanira MO, Nemmar A (2008) Some phytochemical, pharmacological and toxicological properties of ginger (Zingiber 
officinale Roscoe): a review of recent research. Food Chem Toxicol 46:409-420

Chen JH, Cui GY, Liu JY, Tan RX (2003) Pinelloside, an antimicrobial cerebroside from Pinellia ternata. Phytochemistry 64:903-906

Chung HS, Um JY, Kim MS, Hong SH, Kim SM, Kim HK, Park SJ, Kim SC, Hwang WJ, Kim HM (2002) Determination of the site of origin of Pinellia ternata roots based on RAPD analysis and PCR-RFLP. Hereditas 136:126-129

Gonda R, Tomoda M, Shimizu N, Ohara N, Takagi H, Hoshino S (1994) Characterization of an acidic polysaccharide with immunological activities from the tuber of Pinellia ternata. Biol Pharm Bull 17:1549_ 1553

Huang HC, Chiu SH, Chang TM (2011) Inhibitory effect of [6]-gingerol on melanogenesis in B16F10 melanoma cells and a possible mechanism of action. Biosci Biotechnol Biochem 75:1067-1072

Iwasa M, Iwasaki T, Ono T, Miyazawa M (2014) Chemical composition and major odor-active compounds of essential oil from Pinellia tuber (dried rhizome of Pinellia ternata) as crude drug. J Oleo Sci 63:127-135

Jeon MJ, Kim MY, Jang HJ, Lee SW, Kim JH, Kim HS, Lee SH (2012) Whitening effect of Hizikia fusiformis ethanol extract and its fractions. J Life Sci 22:889-896

Ji X, Huang B, Wang G, Zhang C (2014) The ethnobotanical, phytochemical and pharmacological profile of the genus Pinellia. Fitoterapia 93:1-17

Jiang H, Solyom AM, Timmermann BN, Gang DR (2005) Characterization of gingerol-related compounds in ginger rhizome (Zingiber officinale Rosc.) by high-performance liquid chromatography/electrospray ionization mass spectrometry. Rapid Common Mass Spectrom 19:2957-2964

Kim JS, Lee SI, Park HW, Yang JH, Shin TY, Kim YC, Baek NI, Kim SH, Choi SU, Kwon BM, Leem KH, Jung MY, Kim DK (2008) Cytotoxic components from the dried rhizomes of Zingiber officinale Roscoe. Arch Pharm Res 31:415-418

Kim KO, Ku CS, Kim MJ, Park YJ, Ryu HW, Song HH, Kim JH, Oh SR
(2015) Phytoecdysones from the roots of Achyranthes japonica Nakai and their anti-atopy activity. J Appl Biol Chem 58:13-19

Kim SH, Jeong H, Kim YK, Cho SH, Min KU, Kim YY (2001) IgEmediated occupational asthma induced by herbal medicine, banha (Pinellia ternata). Clin Exp Allergy 31:779-781

Kim SH (2015) Food and drug statistical yearbook. In: Cho GW, Moon GG, Choi JS, and Jung JW (eds) Imports \& Exports of Biopharmaceuticals \& Herbal Medicine, etc., vol 17. Ministry of food and drug safety, Cheongju, pp 380-387

Kim YJ, Shin YO, Ha YW, Lee SH, Oh JK, Kim YS (2006) Anti-obesity effect of Pinellia ternata extract in zucker rats. Biol Pharm Bull 29:12781281

Nagai T, Shimizu Y, Shirahata T, Sunazuka T, Kiyohara H, Omura S, Yamada H (2010) Oral adjuvant activity for nasal influenza vaccines caused by combination of two trihydroxy fatty acid stereoisomers from the tuber of Pinellia ternata. Int Immunopharmacol 10:655-661

Peng ZS, Luo CK, Cai P, Mao ZC, Kang CY, Yang J (2007). Rapid propagation of the medicinal plant Pinellia ternata by in vitro leaves culture. Bulg J Agric Sci 13:1-6

Song HH, Moon JY, Ryu HW, Noh BS, Kim JH, Lee HK, Oh SR (2014) Discrimination of white ginseng origins using multivariate statistical analysis of data sets. J Ginseng Res 38:187-193

Song HH, Ryu HW, Kim HS, Kim CS, Hyun HJ, Lee HK, Oh SR (2016) A metabolomics approach to identify factors influencing their activity relative to oleanolic acid contents in Korean mistletoe types. J Funct Foods 22:64-72

Zhang ZH, Zhao YY, Cheng XL, Ling RC, Dai Z, Zhou C (2013) Metabonomic study of biochemical changes in the rat urine induced by Pinellia ternata (Thunb.) Berit. J Pharm Biomed Anal 85:186-193

Zuo Z, Fan H, Wang X, Zhou W, Li L (2012) Purification and characterization of a novel plant lectin from Pinellia ternata with antineoplastic activity. Springerplus 16:1 